Saudi Journal of Humanities and Social Sciences

Abbreviated Key Title: Saudi J Humanities Soc Sci

ISSN 2415-6256 (Print) | ISSN 2415-6248 (Online)

Scholars Middle East Publishers, Dubai, United Arab Emirates

Journal homepage: http://scholarsmepub.com/sjhss/

Original Research Article

\title{
Appraisal of Slum Upgrading In Cameroonian Cities: A Twin-Track City Management Framework for Adequate and Decent Affordable Housing
}

\author{
Clarkson Mvo Wanie (Ph.D)* \\ Department of Geography and Planning, Faculty of Arts, the University of Bamenda, Bambili, Cameroon
}

DOI: $10.36348 /$ sjhss.2019.v04i12.007

| Received: 17.12.2019 | Accepted: 25.12.2019 | Published: 30.12.2019

*Corresponding author: Clarkson Mvo Wanie (Ph.D)

\section{Abstract}

The proliferation of slum residential areas in cities in Sub Saharan Africa adversely affects the inhabitants through overcrowding and congestion, sub-standard housing development, disease prevalence, inadequate socio-economic infrastructures such as potable water supply, hygiene and sanitation facilities, wastes disposal schemes and drainage channels, the prevalence of crime and violence and environmental hazards such as floods and landslides. In Cameroon, slums continue to appear in cities and towns because of poor urban governance which fails to ensure effective and comprehensive city management strategy in order to prevent new slum neighbourhoods from emerging in the urban landscape and make existing ones more livable and sustainable. This study makes an appraisal of slum upgrading in Cameroonian cities and proffers a twin-track planning solution that will ensure an effective and comprehensive city management for urban sustainability. To do this, on-the-spot appraisals, field surveys and participatory appraisals were undertaken with individual slum households, quarter heads, municipal authorities, CIGs and NGOs working with slum dwellers and government ministries in charge with urban development for a period of twelve months. Analysis was done using descriptive techniques. Findings showed that the Participatory Slum Upgrading Programmes (PSUP) launched in 2008 and implemented by UN-Habitat which aims to improve the living conditions of slum dwellers is the current slum upgrading approach used in Cameroon. But an appraisal of the problems plaguing this approach shows that much still need to be done to assure adequate and decent affordable housing. Tenure security, financial difficulties, displacement/forced evictions, coordination of actors, follow-ups, determination of slum sites and their full coverage, the non-respect of building/construction norms during resettlement, trivial help from international donors, lack of technical expertise, government neglect and lack of political will and the socio-political unrest experienced in some regions of the country all constitute the main limiting factors to the success of the PSUP approach. These problems provide indicators for the need of an effective and comprehensive city management strategy beyond the PSUP approach which does not only improve the physical living conditions but also ameliorate the legal, economic, political and social wellbeing of the urban poor slum dwellers now and for the long term. For urban sustainability to be realised in Cameroonian cities, I proffer the City Development Strategy (CDS) framework as a twin-track holistic, proactive, forward-looking and citywide slum upgrading approach. The CDS is an effective and comprehensive city management approach which can simultaneously improve the living conditions of existing slums dwellers and prevent the formation of new ones amongst Cameroonian cities thereby contributing to meeting the SDG target on access to adequate and decent affordable housing and services by all.

Keywords: Slum, urban governance, urban sustainability, PSUP, Cameroon.

Copyright @ 2019: This is an open-access article distributed under the terms of the Creative Commons Attribution license which permits unrestricted use, distribution, and reproduction in any medium for non-commercial use (NonCommercial, or CC-BY-NC) provided the original author and source are credited.

\section{CONTEXT OF THE STUDY}

Slums as defined by [1] refer to areas in cities lacking one or more of the following indicators; a durable housing structure, access to clean water, access to improved sanitation, sufficient living space and secure tenure. The first four rely on conventional definitions; the last is the most difficult to assess and is not currently used in slum measurement. This implies that slum dwellers face problems such as poor housing, insecure tenure, and inequalities in access to utilities. They are characterised by a lack of basic services, substandard housing or illegal and inadequate building structures, overcrowding and high density, unhealthy living conditions and hazardous location, insecure tenure, irregular or informal settlements, poverty and social exclusion and minimum settlement size [1]. 
The number of people residing slums have always been on the increase the world over. One third of the world's urban population, some one billion individuals, lives in slums [2]. [3-4] estimates that about 1 billion people currently live in slum settlements (almost a third of the world's urban population). [3] further estimated that this could increase to 3 billion by 2050. In 2012 alone for instance, an estimated 863 million urban residents worldwide lived in slum conditions, compared with 760 million in 2000 and 650 million in 1990 [5]. In 2014, the UN-Habitat placed the global estimate of slum populations at 881 million, just under a third of all urban-dwellers in the developing world [6]. The global slum population will probably grow by six million each year, pushing the total number to 889 million in another 10 years [7].

The world is urbanizing inexorably and this trend, according to demographers, is henceforth essentially taking place in emerging and developing countries, first of all in Asia and Africa, and to a lesser extent, in Latin America. In these countries, about two billion people currently live in an urban environment [2]. According to United Nations forecasts [8], this figure could double within the next thirty years. By 2011 , it was estimated that more than one billion of these poverty-stricken urban dwellers lived in slums [2].

An overwhelming $94 \%$ of slum dwellers live in the developing countries [2], including Africa. In African cities and towns, [9] described a prevailing urban condition across the continent known as the challenge of "slum urbanism". Slum urbanism refers to a prevailing urban condition that is evident in cities and towns across the African continent whereby slum dwellers continue to develop their own cities because the state and the formal market do not yet have the capacity to address the escalating demand for land, housing, and services. While a marked variation exist in the prevalence of slums across the African continent, Cameroon falls under the countries with a high rate of slum development with 60-79\% [10], as shown in Table 1 .

Table-1: Variations in the prevalence of slums among African Countries

\begin{tabular}{|c|c|c|c|}
\hline Very High $(>80 \%)$ & $\begin{array}{l}\text { High } \\
(60-79 \%)\end{array}$ & Moderate (40-59\%) & Low $(<40 \%)$ \\
\hline $\begin{array}{l}\text { Angola } \\
\text { Benin } \\
\text { Central African } \\
\text { Republic } \\
\text { Chad } \\
\text { Congo } \\
\text { Equatorial Guinea } \\
\text { Ethiopia } \\
\text { Guinea-Bissau } \\
\text { Madagascar } \\
\text { Malawi } \\
\text { Mali } \\
\text { Mauritania } \\
\text { Mozambique } \\
\text { Niger } \\
\text { Rwanda } \\
\text { Sierra Leone } \\
\text { Sudan } \\
\text { Tanzania } \\
\text { Togo } \\
\text { Uganda }\end{array}$ & $\begin{array}{l}\text { Botswana } \\
\text { Burkina Faso } \\
\text { Burundi } \\
\text { Cameroon } \\
\text { Comoros } \\
\text { Cape Verde } \\
\text { Cote d'Ivoire } \\
\text { Eritrea } \\
\text { Gabon } \\
\text { Gambia } \\
\text { Ghana } \\
\text { Guinea } \\
\text { Kenya } \\
\text { Nigeria } \\
\text { Senégal } \\
\text { Zambia }\end{array}$ & $\begin{array}{l}\text { Democratic Republic of } \\
\text { Congo } \\
\text { Lesotho } \\
\text { Liberia }\end{array}$ & $\begin{array}{l}\text { Algeria } \\
\text { Egypt } \\
\text { Libya } \\
\text { Morocco } \\
\text { Namibia } \\
\text { South Africa } \\
\text { Tunisia } \\
\text { Zimbabwe }\end{array}$ \\
\hline
\end{tabular}

Source: Arimah (2010)

Sub-Saharan Africa (SSA), where Cameroon is found is the region with the highest proportion of the urban population living in slums with over $50 \%$ compared to figures ranging between $20 \%$ and $31 \%$ for other regions of the world [11]. This is shown in Figure 1. 


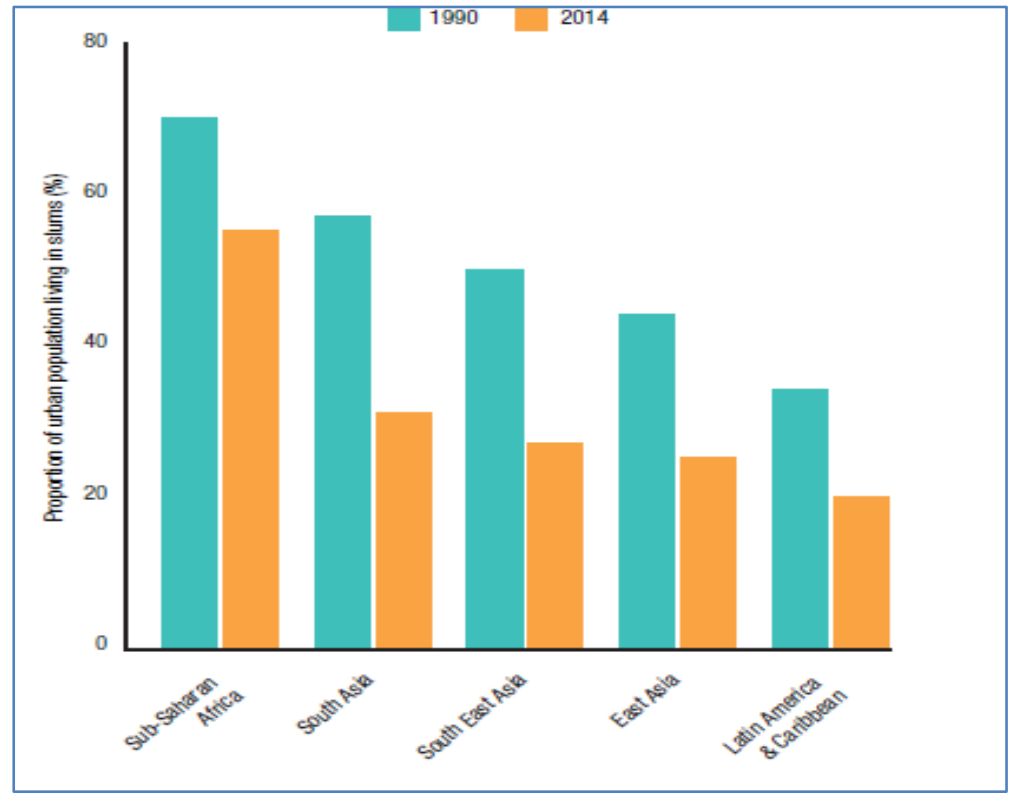

Fig-1: Proportion of urban population living in slums by region (1990-2014) Source: UN-Habitat (2014)

In most SSA cities and towns, slum urbanism is driven by a self-fulfilling cycle that drives urban development patterns as illustrated in Figure 2.

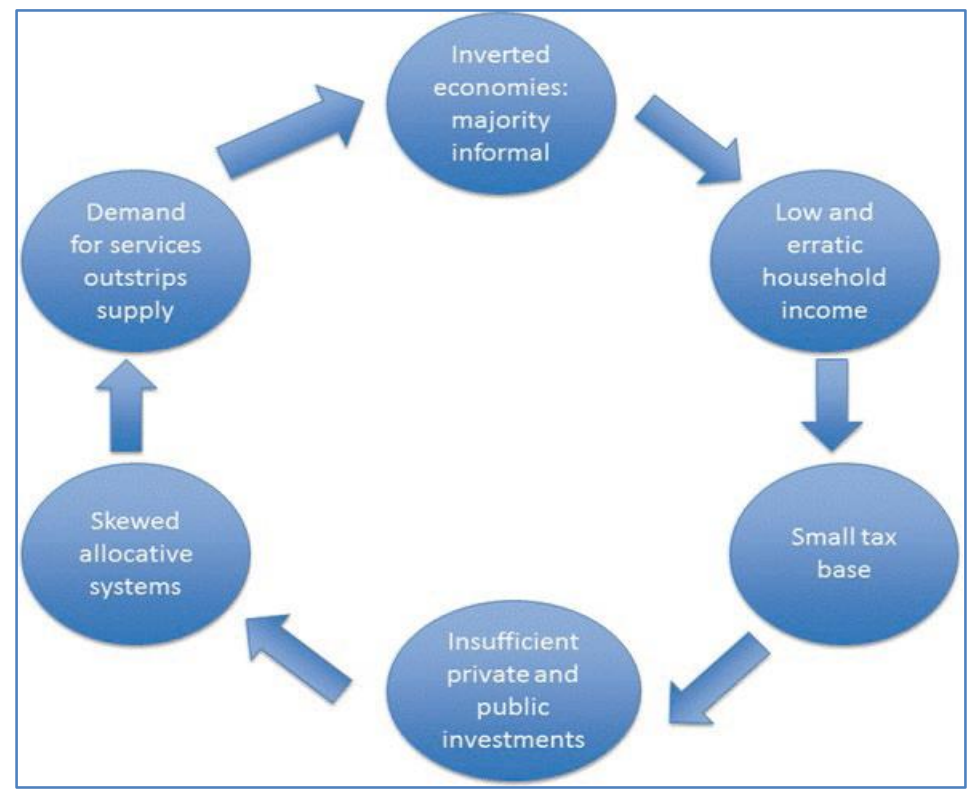

Fig-1: Urban development cycle in SSA: "Slum Urbanism" Source: Pieterse (2013)

Slum upgrading, which is the principal component of the UN-Habitat Global Housing Strategy addressing housing conditions in cities, is widely recognized as the most proactive and effective way of improving the housing conditions and lives of the millions of low-income and BOP (bottom-of-thepyramid) households living in slums in African cities and towns, and thereby contributing to the achievement of Sustainable Development Goal 11: ensuring access for all urban households to adequate, safe, and affordable housing and basic services, as well as upgrading slums, by 2030 [5]. The Sustainable
Development Goals (SDGs), specifically Goal 11, aims to 'make cities and human settlements inclusive, safe, resilient, and sustainable', with its first target seeking to 'ensure access for all to adequate, safe and affordable housing and basic services, and upgrade slums' [12].

Slum conditions in cities and towns in Cameroon like their counterparts in SSA are appauling. The slum inhabitants have to constantly deal with issues such as lack of access to the most basic human requirements; water, sanitation, shelter, health, electricity, education, no sewage or solid waste disposal 
facilities, lack of public transit, pollution and housing shortages. Mortality is also high in the slums. The problems these causes range from impairment of human health, to economic and other welfare losses and to damage of the ecosystem.

[13] highlighted that historical trends on slum growth, particularly in SSA (and Cameroon), will need to reversed to have any chance of meeting the SDG target on access to adequate housing and services. One way to achieve such is through slum upgrading, which consists of "physical, social, economic, organizational, and environmental improvements undertaken cooperatively and locally among citizens, community groups, businesses, and local authorities" [1].

Upgrading living conditions in slum areas is a key challenge that governments, including the government of Cameroon, have to face towards the drive of meeting the emergence goal by 2035 [4] explained slum upgrading as a process through which informal areas are gradually improved, formalised and incorporated into the city itself, through extending land, services and citizenship to slum dwellers. It involves providing slum dwellers with the economic, social, institutional and community services available to other citizens. These services include legal (land tenure), physical (infrastructure), social (such as crime or education) or economic. Upgrading activities is usually undertaken by the local government with the participation of all parties-residents, community groups, businesses, and national authorities. The aim of upgrading is to eliminate unhealthy, unsanitary, or unsafe conditions, lessen density, eliminate obsolete or other uses detrimental to public welfare, or other wise to remove or prevent the spread of blight or deterioration, or to provide land needed for public facilities [14].

Usually carried out in densely built and dilapidated urban areas aimed at improving the physical, environmental and living conditions of slum areas, slum upgrading is inevitable because people have a fundamental right to live with basic dignity and in decent conditions. It is also in a city's best interest to upgrade slums and prevent new ones from forming. If slums are allowed to deteriorate, governments can lose authority within a city, exposing slum dwellers to informal systems of service provision and control, with slums becoming areas of crime and disease that can affect the whole city and country. As such, slum upgrading is one of the most viable and affordable ways to provide housing to the urban poor and can be implemented incrementally. The report drafted by the United Nations on the occasion of the New York Summit of 2005 indirectly defined five key drivers necessary for promoting slum-free urban development; access to water, sanitation, security of land tenure [2], building sustainable housing, and sufficient living space.
According to [15], slums are an ongoing and dominant feature of Cameroon's urban centres. More than half of Cameroonians now live in towns and cities (53\% or around 13 million of Cameroon's estimated 23 million) and an estimated $60 \%$ of those are living in informal settlements and slums. With an urban growth rate of around $54 \%$, the challenge of managing and preventing slums in the country is critical.

As [16] equally reported that in 2010, some $70 \%$ of the population of Cameroon lived in unplanned settlements (slums) with the majority of peri-urban residents living in poorly drained and poorly serviced areas. Notwithstanding the massive slums evident in Cameroonian cities and towns, upgrading has been slowly done and only recently has serious attention and the political will been accorded to it. While several good practice case studies and individual assessments on slum upgrading programmes which reflect 'best practice' examples which delivers positive results exist in Latin America and Asia, it is difficult to find such in Cameroon. Existing and on-going slum upgrading projects this far does not usually provide the necessary results as the slum-upgrading interventions are not always successful in providing adequate and decent affordable housing to the slum dwellers. This is partly because the comprehensive parameters of upgrading have hardly been succinctly identified or outlined. More so, proactive planning strategies are not been employed to upgrade the slum areas as in most cases houses proliferate before planning is done (back to front planning). Also, impact evaluation of slum upgrading is lacking, as well as follow-ups of the outcome. Once started, some of the upgrading projects end up half way. Again, the beneficiaries of some government sponsored upgrading projects such as the "low cost' or "social housing" schemes have not been strictly defined. As such, the intended beneficiaries (slum dwellers) are not targeted by upgraded housing projects in cities and towns. As [5] equally found out, heavily subsidized housing (social housing in Cameroon) is unaffordable for the originally targeted slum dwellers and ends up being occupied by middle-income households. As a result, slum areas will not cease to emerge in our cities as the urban poor will utilise every opportunity to 'improvise' their own housing to shelter themselves and their families especially for the short term.

There is need to appraise slum upgrading in Cameroonian cities and profuse a holistic and proactive planning solution for effective and comprehensive city management and development, which is an aspect poorly tackled before. This study therefore aims to appraise slum upgrading and suggest a proactive planning solution for effective and comprehensive city management as cities play a proactive role in addressing sustainability. It explores the actors, current upgrading approach; problems faced and frame a proactive citywide planning framework for effective and 
comprehensive city management resulting to sustainable cities and adequate and decent affordable housing in Cameroonian cities.

\section{RESEARCH METHODS}

The research methods employed for this study consisted of data collection and data analysis. Data collection employed two sources; secondary and primary. Secondary sources involved published materials from textbooks, journal articles, UN Habitat, UN DESA, UN and City Alliance reports and the consultation of internet websites. Primary sources employed four complementary and participatory appraisals with individual slum households, NGOs and CIGs and municipal authorities for over twelve months. These include reconnaissance surveys, stratified sampling of slum neighbourhoods, interviews and questionnaires administration. Reconnaissance surveys were undertaken between January 2019 and August 2019 to identify slum areas in five selected cities and towns in Cameroon (Douala, Limbe, Tiko, Yaounde and Bamenda) in four of the ten regions in Cameroon as shown in Figure 3.

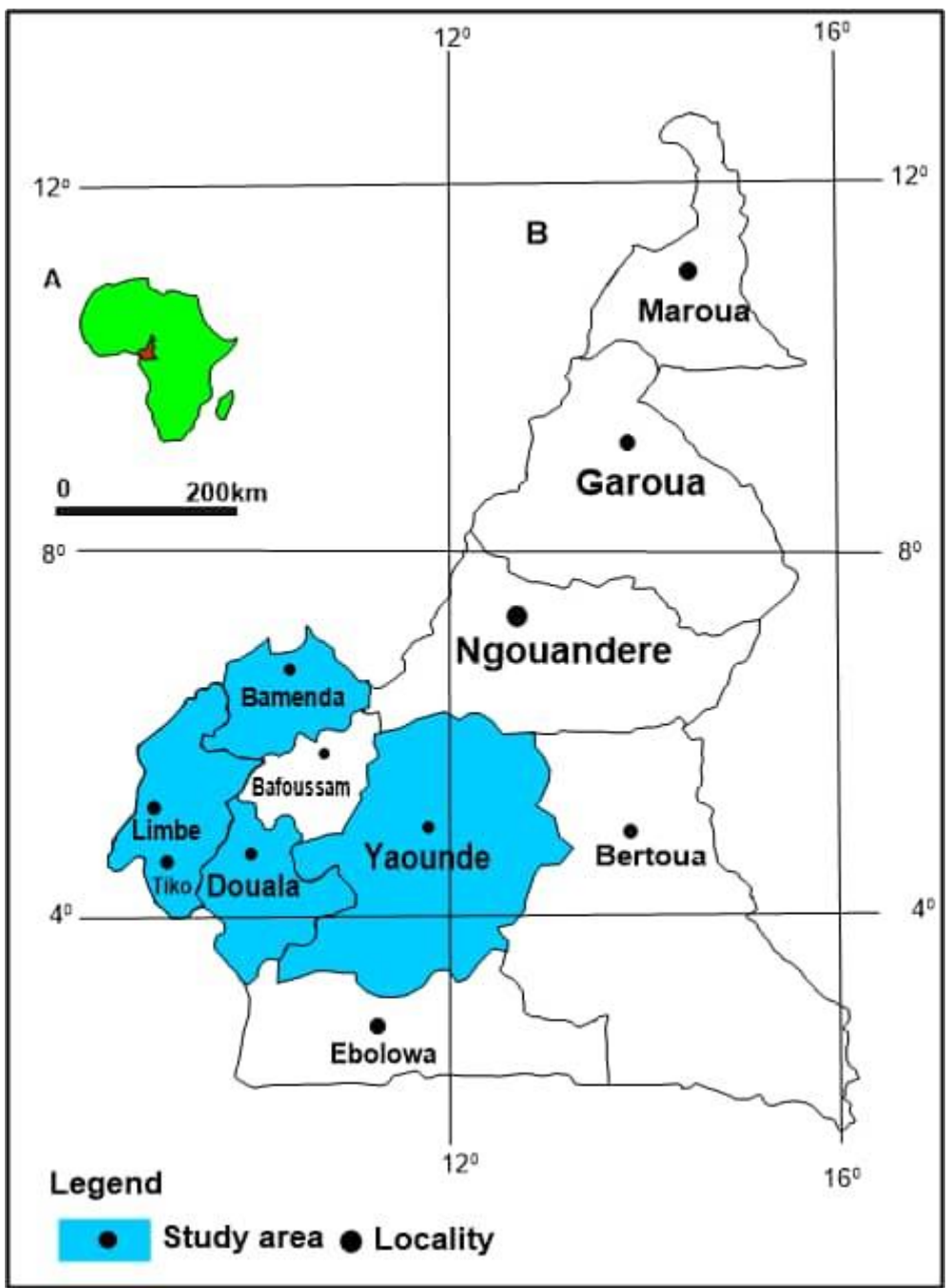

Fig-3: Location of the study areas (cities)

This was followed by the use of the stratified sampling procedure in the administration of the questionnaires. Stratification limited questionnaire administration strictly to residents of slum neigbourhoods in the selected study areas. A total of 140 questionnaires were successfully administered and retrieved, with the help of field assistants. Interviews were further granted with administrative authorities (quarter heads and municipal authorities in charge of urban development) to ascertain the slum upgrading strategies and problems faced in their various municipalities. All these methods helped in attaining the stated objectives of the study. Analysis of collected data was done using descriptive methods.

\section{RESULTS AND DISCUSSION}

The approach currently used for slum upgrading in Cameroon is mainly the Participatory Slum Upgrading Program (PSUP) implemented by UNHabitat that was launched in 2008. It aims at improving the living conditions in towns and cities and positively contributes to the Millennium Development Goal 7 which focuses on improving the lives of slum dwellers 
by 2020. The PSUP in Cameroon works through the Quito Implementation Platform to prepare for city-wide slum upgrading. While this type of participatory slum upgrading logic (PSUP) is essential for sustainable urban action, it failed in the restructuring and urban planning project in the Nylon zone in the city of Douala (which suffered the strongest demographic growth and the greatest official neglect), in the construction of roads and drainage systems, the installation of collective equipment, regular landownership, housing credits, the relocation of families affected by the works, the promotion of crafts and of employment in general, and support for basic community organizations [2].

The PSUP approach in Cameroon is carried out with the help of international, national, regional and local stakeholders. These stakeholders are also public, private, community-based, individual and institutional. Some of these stakeholders include UN Habitat; the Central government (MINDUH-Ministry of Housing and Urban Development, MINEPAT-Ministry of the Economy, Planning and Regional Development; MINSEC-Ministry of Secondary Education, MINSANTE-Ministry of Public Health, MINEDUBMinistry of Basic Education; MINTP-Ministry of Public Works, MINEE-Ministry of Energy and Water Rersources, etc); parastatals including FEICOM (Fonds Spécial d'Equipement et d'Intervention Intercommunale), CFC (Crédit Foncier du Cameroun), MAETUR (Mission d'Aménagement et d'Equippement des Terrains Urbains et Ruraux) and SIC (Société Immobilière du Cameroun); agro-industrial plantations; local governments (decentralized collectivities); community organisations; NGOs and CIGs; quarter heads; landlords and private individuals. The involvement of these diverse stakeholders was because of the recognition that slum upgrading is critical to sustainable urbanization in the country, after approving in 2004 the first law governing urban development (' $L a$ Loi Régissant l'Urbanisme') requiring city councils to develop master plans.

The PSUP approach currently used in slum upgrading initiatives in Cameroonian cities focus on demolition of buildings, refurbishment of buildings, provision/access to socio-economic amenities (sewerage, street lights, bridges, transportation infrastructure, recreational spaces, schools, toilets, water, electricity, reforestation or urban forest, child care centres, etc) and improvement of environmental conditions. Prominent examples at the implementation phase (upon completion of the urban profiling and action planning and programme document formulation) of PSUP initiatives in Cameroon are found in three project cities (Yaoundé, Bamenda and Kribi) (Figure 4).

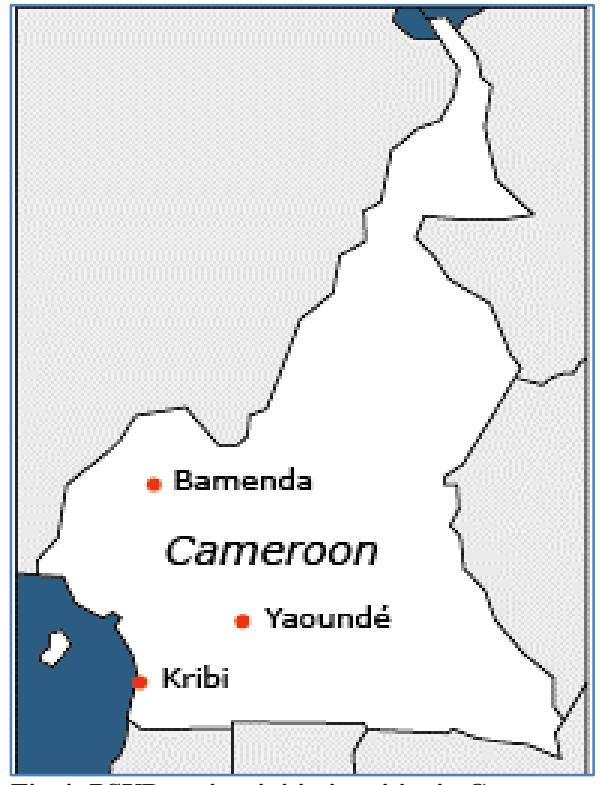

Fig-4: PSUP project initiative cities in Cameroon

Source: UN Habitat country profile: Cameroon (2019)

The PSUP initiatives help to improve the physical living conditions in slum settlements in Cameroonian cities. Besides the UN-Habitat PSUP implementation initiatives in the above three Cameroonian cities, Plates 1 and 2 show some other piecemeal and user-initiated slum and informal settlement upgrading efforts by the agro-based industrial plantation (Cameroon Development Corporation) and private individuals.
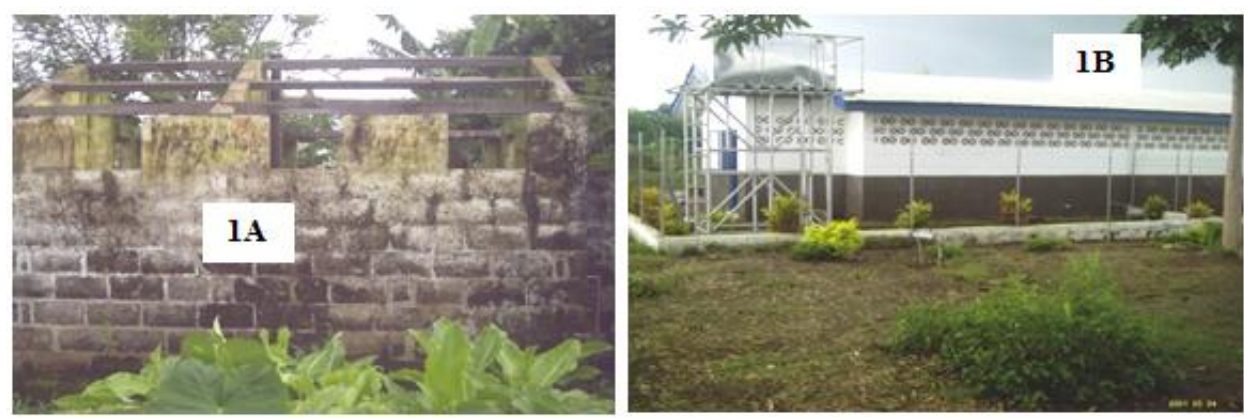

Plate-1: (A) A dilapidated communal pit toilet in the CDC Plantation camp at Upper Costain, Tiko before upgrading prior to 2008. (B) A modern water system facility toilet at Upper Costain Tiko after upgrading in 2008 through the infrastructural addition upgrading method. Similar modern toileting structures have equally been built in other plantation camps in Tiko including Water Tank and Clerk's Quarters. Source: Wanie (2008) 


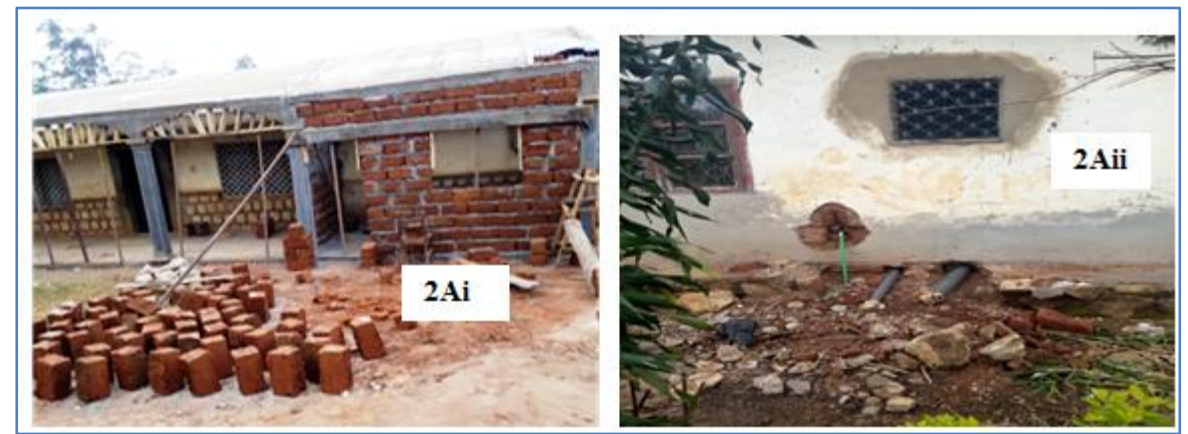

Plate-2: Urban housing refurbishment dynamics in cities: (A) On-going privately initiated housing refurbishment with mud blocks at Centerbolt, Nkwen in Bamenda by adding the number of rooms, internal water supply system/flushed toilet, tiles and paint. 2Ai is the front view while 2Aii is the side view of the building. Source: Fieldwork (January, 201 9)

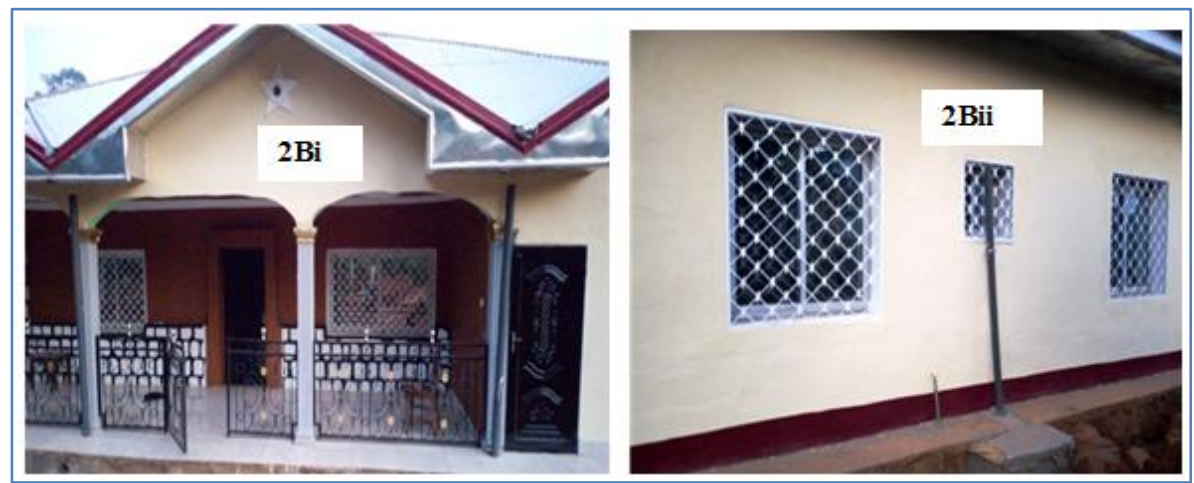

(B) Building after renovation. 2Bi is the front view while 2Bii is the side view of the refurbished building. Source: Fieldwork (December, 2019)

A critically examination of the PSUP approach of slum upgrading in Cameroonian cities shows that as a result of several problems faced, it has failed to make decent affordable housing adequate for the urban poor slum dwellers as noted by UN-Habitat (2005) for African countries, with Cameroon not an exception. Analysis of responses of the problems plaguing the effective and comprehensive slum upgrading initiatives in Cameroonian cities as a result of poor urban governance and city management reveals the following sixteen (16) problems summarized in Table 2 .

Table-2: Problems plaguing the effective and comprehensive slum upgrading Initiatives in Cameroonian cities

\begin{tabular}{|l|l|c|c|}
\hline S/N & \multicolumn{1}{|c|}{ Problem identified } & f & cf \\
\hline 1 & Inexhaustibly outlined upgrading parameters & 9 & - \\
\hline 2 & Tenure security & 29 & 38 \\
\hline 3 & Financial constraints & 21 & 59 \\
\hline 4 & Non-respect of building/construction codes during upgrading & 10 & 69 \\
\hline 5 & Trivial assistance from international donors & 3 & 72 \\
\hline 6 & Lack of consultation and involvement of expertise technical staff & 6 & 78 \\
\hline 7 & Socio-political unrest in some regions & 2 & 80 \\
\hline 8 & Lack of skills/capacity constraints & 9 & 89 \\
\hline 9 & Slow integration of evicted slum dwellers into the formal city & 3 & 92 \\
\hline 10 & Displacements, forced eviction and non-compensation of evicted slum & 7 & 99 \\
& dwellers & & \\
\hline 11 & Resistance by the population against eviction & 2 & 101 \\
\hline 12 & Problem of coordination of upgrading actors & 3 & 104 \\
\hline 13 & Hazard occurrence and mitigation in the upgraded slums & 4 & 108 \\
\hline 14 & Problem of follow-up & 3 & 111 \\
\hline 15 & Unplanned site location of slum settlements & 9 & 120 \\
\hline 16 & Government neglect and lack of political will & 20 & 140 \\
\hline
\end{tabular}

Source: Fieldwork (2019) (f=frequency; cf=cumulative frequency)

Analysis of the problems encountered in slum upgrading in Cameroonian cities as indicated in Table 2 indicates that the problem of tenure security is the most outstanding problem as outlined by some $29 \%$ of the population. This implies that most of the residents in the upgraded slum neighbourhoods have not been issued 
land titles on the land they occupy. This is because the process of land titling in Cameroon is a cumbersome and lengthy process, which is often approved after construction must have been completed. As such, the slum dwellers constantly 'squat' on the land they occupy. For instance, a study by [16] revealed that $50 \%$ of squatter settlements in Limbe and only $20 \%$ in Tiko had a Building Permit from the local planning authorities.

The problem of tenure security was closely followed in the second place by the problem of finance (21\%), as most of the slum dwellers, NGOs and CIGs and even the national government lack adequate finances to carry out upgrading initiatives. The problem of finance in slum upgrading partly justifies why upgrading initiatives in most African countries is often done with the support of foreign bilateral and/or multilateral donors [2]. Pinpointing some of the permanent features which should be contemplated in the future of slum grading, the author highlighted that "a large majority of slum upgrading operations are conducted beyond the range of regular local and national government budgets". He further noted that "when comparing investments required to successfully run a city on tangible and intangible levels, funds earmarked for slum upgrading actions are, almost systematically, very modest and limited in time". All these assertions reiterate the problem of inadequate finance in slum upgrading initiatives in Africa, with Cameroon not an exemption.

The problem of government neglect and lack of political will towards slum upgrading followed third with $20 \%$. [2] observed that with the negligence of governments, the most energetic residents develop autonomous strategies and launch measures to solve their daily problems independently, and on their own terms. The result is the widespread proliferation of slums in the urban landscape. In their studies, [5] and [2] equally confirmed that the lack of political will by governments is one of the factors combining to result to the development of slums in cities and towns in Africa, with Cameroon included.

The non-respect of building/construction norms during upgrading initiatives constitutes $10 \%$ of the problems faced in slum upgrading. Inexhaustibly outlined upgrading parameters and the lack of skills/capacity constraints of community organisation such CIGs and NGOs and the fragile or marginal unplanned sites occupied by slums which render upgrading efforts difficult were other problems that closely followed the above four constituting $9 \%$ each.

Furthermore, other problems that were equally identified were the problems of displacement and forced eviction for upgrading to take place and the noncompensation of evicted slum dwellers which constituted $7 \%$ of the problems faced. Eviction is a continuous process of destruction and expulsion and around the world, some 6.7 million people were evicted from their homes between 2000 and 2002 [17].

Another identified problem was the lack of consultation and involvement of expertise technical staff $(6 \%)$ in the building of drainage and sewerage systems, waste collection, street network, etc which makes some upgraded projects hazardous to the slum residents. This problem was closely followed by that of mitigating hazards (4\%) such as floods and landslides in the upgraded slums. Floods for instance are a yearly occurrence in some upgraded slum neighbourhoods especially in coastal towns such as Mabeta in the southwest coast of Limbe, Customs Beach in the Tiko estuarine environment and Bonaberi in Cameroon's economic capital of Douala.

More so, trivial help from international donors, slow integration of evicted slum dwellers into the formal city and the problem of coordination of the actors and follow-up of the upgraded slum areas such as tree planting constituted $3 \%$ each of problems identified by NGOs and CIGs involved in slum upgrading. The lack of follow-ups in the upgraded slum neigbourhoods for instance, causes them to go back to their initial condition such as was the case in the Nylon project in Douala where some 20 years after completion of works, roadways are impracticable and amenities were in a bad state of repair [2]. Also, mobilising all the different actors involved in the process of slum upgrading at the national and most importantly, the local level in a different and conclusive manner is a herculean task [2].

Finally, the socio-political unrest witnessed in the two Anglophone regions (Northwest and Southwest) of the country since late 2016 and which escalated in 2017 into an armed conflict between government forces on the one hand and separatist's fighters on the other as well as resistance by the local population towards eviction such as in Bonaberi (Douala) and Bimbia (Limbe) for upgrading to take place each constituted $2 \%$ of the problem encountered in upgrading initiatives.

Based on the above problems, a holistic and proactive planning solution which equally addresses other non-physical upgrading parameters in the slums is therefore required for sustainable city management and development to be achieved in Cameroon. This sustainable planning approach is suggested in the paragraph below.

Although the current PSUP initiatives help to improve the physical living conditions in slum settlements, they are not exhaustive as they focus mainly on rebuilding houses, adding socio-economic infrastructure and improvement of environmental conditions (physical aspects). Other non-physical slum upgrading parameters or imperatives that should equally be addressed for sustainable city management to be 
effective and comprehensive in Cameroon include addressing land titling, tenure security, community development and organisation, jobs creation and income generating activities or opportunities in the slums. At this juncture, I suggest the City Development
Strategy (CDS) framework (Figure 5), which is a strategy that layout the agenda and provide the impetus for effective and comprehensive city management, as a twin-track proactive planning solution to address slums in Cameroonian cities.

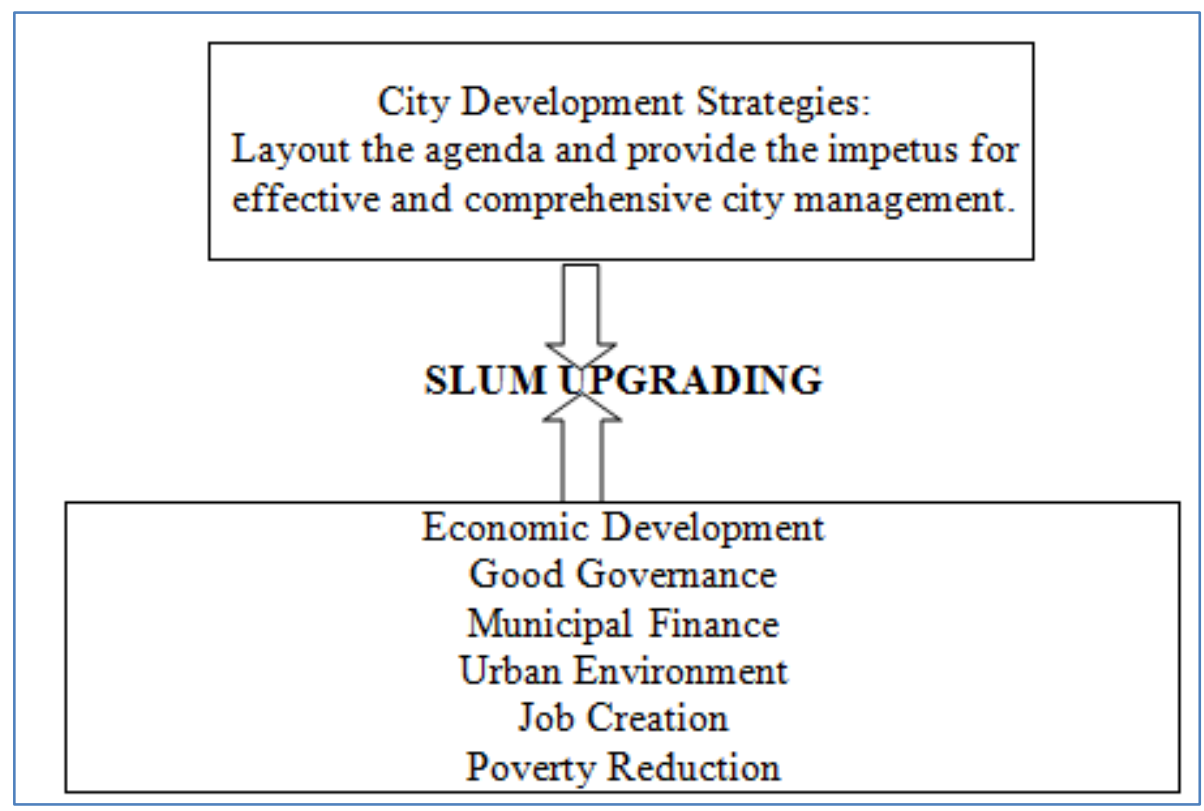

Fig-5: A proactive CDS framework for slum upgrading in Cameroon

Source: Culled from Wanie (2008) and Wanie and Fombe (2010)

The CDS is a holistic, proactive and forwardlooking city-wide urban planning and slum upgrading strategy that can simultaneously improve housing conditions and the quality of life in slums. It forms an integral component of city development, including economic development, good governance, municipal finance, urban environment, job creation, and poverty reduction. It thus has a considerable impact on the ability of cities to manage the needs of the urban poor residents living in slums by improving living conditions of existing slum dwellers and preventing the formation of new ones (twin-track solution) in Cameroon's cities and towns if well managed because cities play a proactive role in addressing sustainability. The CDS framework suggested by this study is in line with [9] who maintained that slum urbanism can only be "interrupted, disassembled, and remade" by the "articulation of an effective package of economic, governance, and political-cultural reforms, by civil society organizations rooted in the interest of the urban poor", which are issues that if corrected managed, the CDS framework can achieve in Cameroon.

\section{CONCLUSION AND RECOMMENDATIONS}

The prospect of slum upgrading in Cameroonian cities is bright if urban management and development stakeholders move away from the traditional piecemeal slum upgrading approaches that concentrate on improving solely the physical living conditions of the slum dwellers to a more proactive, holistic and forward-looking one that forms an integral component of city development strategies, including economic development, good governance, municipal finance, urban environment, job creation, and poverty reduction. This study therefore strongly recommends the CDS framework presented in Figure 5 as a sustainable city development approach through which sustainable cities can be achieved in Cameroon. The CDS framework forms the nexus through which the physical on the one hand and the economic, political and social aspects of slum upgrading on the other can be tackled simultaneously. This strategy, if well managed, besides improving the lives of the urban poor living in slums will equally prevent new slum neighbourhoods from developing thereby resulting to sustainable city development in Cameroon and meeting the SDG target on access to adequate housing and services by all. Also, special planning and building codes should be granted to slum areas undergoing upgrading by municipal authorities as a Special Social Interest Area (SSIA). Those on public lands should equally be granted the tenure security of remaining on the land and using it, rather than displace them. This will give the slum residents the confidence to improve on their home. Tenure regulations would further help to include upgraded slums into the formal fabric of cities. This is important because the problem of tenure security was raised or mentioned to be the greatest (29\%) of all the problems plaguing slum upgrading currently in Cameroonian cities. 


\section{REFERENCES}

1. UN-Habitat. (2003). The challenge of slums: Global report on human settlements 2003, Earthscan Publications Ltd, 345p.

2. Bolay, J.C. (2011). "Slum Upgrading: Interdisciplinary Perspective and Intersectoral Action towards Urban Sustainable Development". Paper Presented in Track 3: Housing and Community Development at the 3rd World Planning Schools Congress, Perth (WA), 4-8 July 2011.

3. UN DESA. (2013). World Economic and Social Survey: Sustainable Development Challenges. New York: United Nations Department of Economics and Social Affairs (www.un.org/en/development/desa/policy/wess/we ss_current/wess2013/WESS2013.pdf).

4. Cities Alliance. (2014). 'About Slum Upgrading' (www. citiesalliance.org/sites/citiesalliance.org/files/CA_I mages/SUFactsheet_English_0.pdf).

5. Bah, El-hadj, M., Faye, I., \& Geh, Z.F. (2018). Slum Upgrading and Housing Alternatives for the Poor. In: Housing Market Dynamics in Africa, 215253. https://doi.org/10.1057/978-1-137-59792-2_6.

6. UN-Habitat. (2014). Global Urban Indicators Database, 2014.

7. Wanie, C.M. (2012). The silent tsunami in the developing world: Case study of slums in the Tiko Municipality, South West Region of Cameroon', 2012, International Journal of the Institute for Empirical Research and Sustainable Development, Vol. 8, No. 8, pp 25-41..

8. UN-Habitat (2003b). The challenge of slums: Global report on human settlements 2003, Earthscan Publications Ltd, 345p..

9. Pieterse, E. (2013). Competing Imaginaries of Empowerment in African Cities. Afritecture. Building Social Change, 104-113.
10. Arimah, B. C. (2010). Slums as Expressions of Social Exclusion: Explaining the Prevalence of Slums in African Countries. Nairobi: United Nations Human Settlements Program (UNHabitat).

11. Lucci, P., Tanvi, B., Khan, A., \& Berliner, T. (2015). What Works in Improving the Living Conditions of Slum Dwellers? A Review of Evidence across Four Programmes. Development Progress Dimension Paper, (4).

12. UN. (2015). Sustainable Development Goals. United Nations (https://sustainabledevelopment.un.org/topics).

13. Nicolai, S., Hoy, C., Berliner, T., \& Aedy, T. (2015). Projecting progress: reaching the SDGs by 2030. London: Overseas Development Institute (www.odi.org/publications/9895-sdgs-progressscorecard-projecting-2030-developmentgoals).

14. Wanie, C.M. (2008). Slum development and renewal strategies in the Tiko Municipality, Southwest region of Cameroon. Unpublished MSc Thesis, University of Buea.

15. Pemezel, M. (2019). Cameroon - Impact Story: Fostering political will to create a platform for cooperation between all key stakeholders. UN Habitat. Online at: https://www.worldurbancampaign.org/psup/camero on-impact-story-fostering-political-will-createplatform-cooperation-between-all-key. Retrieved 28/8/2019.

16. Fombe, L. F., \& Wanie, C. M. (2010, February). A planning approach for uncontrolled settlements in the Limbe and Tiko municipalities of Cameroon. In conférence internationale sur L'intégration des quartiers spontanés dans l'urbanisation et les technologies alternatives d'assainissement et d'accès à l'eau potable, Yaoundé (pp. 23-25).

17. Bolay, J. C. (2012). What sustainable development for the cities of the South? Urban issues for a third millennium. International Journal of Urban Sustainable Development, 4(1), 76-93. 